Journal of Contemporary Educational Research

Research Article

\title{
Ideological Characteristics of Art Students and Educational Management Strategies
}

Suqin $\mathrm{Li}^{*}$

Kunming Vocational Academy of Art, Kunming 650028, Yunnan Province, China

Abstract: With the continuous development of the society, the requirements for talents are getting higher and higher, and good moral and ethical qualities have gradually become an essential ability that skills must possess in today's society. For students of art majors, their majors have certain peculiarities, so most of them have more distinctive individual characteristics, and their thinking is generally more active and keen. In the education and management of students of art majors, the vital basis should be the characteristics of students' thinking. The author investigates and analyzes the ideological aspects of art majors and proposes effective strategies for the education and management of art majors, hoping to help the development of art majors.

Keywords: Art majors; Ideological characteristics; Educational management; Effective strategies

Publication date: August, 2020

Publication online: 31 August, 2020

*Corresponding author: Suqin Li, lisuqin@163.com

In recent years, art education has moved from elite education to accessible education, and many schools have opened art majors. Students of art majors generally have more distinctive personalities, lack of collectivism, and are more emotional and less disciplined, which also dramatically increases the difficulty of student education and management. In the process of carrying out education and management activities, it is necessary to guide students' thoughts correctly, to improve the overall quality of art majors continuously, and thus lay a good foundation for their future learning and development.

\section{The ideological characteristics of art majors students}

Art students generally have a distinct ideological profile, see Table 1.

Table 1. Ideological characteristics of art students

\begin{tabular}{ll}
\hline $\begin{array}{c}\text { Ideological } \\
\text { characteristics } \\
\text { of art students }\end{array}$ & \multicolumn{1}{c}{ Concrete expression } \\
\hline & $\begin{array}{l}\text { 1 An active mind and passionate about life. } \\
\text { 2 Lack of understanding of current affairs and } \\
\text { politics. }\end{array}$ \\
& $\begin{array}{l}\text { 3 Thinking only from the surface of things, } \\
\text { without exploring the causes and consequences } \\
\text { of things. }\end{array}$ \\
Active ideology, & $\begin{array}{l}\text { 4 Weak ideas and beliefs, whether it is the value } \\
\text { weak ideals }\end{array}$ \\
& $\begin{array}{l}\text { orientation or ideological and moral concepts are } \\
\text { lacking. }\end{array}$ \\
& $\begin{array}{l}\text { 5. The network has become an essential part of } \\
\text { students' learning and life, and the undesirable } \\
\text { information in the system can easily affect their } \\
\text { outlook on life, values and worldview. }\end{array}$
\end{tabular}

1. Value the development of their personality, like to show themselves.

Outstanding individuality, weak collective attitudes

2. Thinking ahead, but generally, arrogant personality, do not like to talk with others. 3. Outstanding individualism, easy to have conflicts and contradictions with other students. 4. When individual interests and collective interests conflict, it is usually more relevant to their interests.

1. Most art students come from families with relatively privileged living conditions. 2. They have bright ideas about their future Self-awareness development and have clear development goals. and lack of $\quad 3$. They attach great importance to the organizational improvement of their professional ability and discipline artistic accomplishment.

4. They have a one-sided view that a free and relaxed teaching atmosphere is very beneficial to their imaginative thinking and creative talent.

Strong 1. Too much emphasis on professional professional knowledge, ignoring the study of the cultural knowledge, basics.

lack of cultural 2. Cultural cultivation needs to be improved; foundation education is relatively narrow, lack of humanism. 


\section{Practical strategies for educating and managing arts students}

\subsection{Building the "Three Teams"}

If you want to make the management of art primary student education management more smoothly, you need to increase the construction of student workforce, and establish a "three teams", see Table 2 .

Table 2. Three teams

\begin{tabular}{|c|c|}
\hline Three teams & Concrete content \\
\hline Counsellors & $\begin{array}{l}\text { 1. Counsellors are an essential core force in the } \\
\text { educational management of art students. Their } \\
\text { professional level and professional quality are } \\
\text { directly related to the quality of students. Therefore, } \\
\text { as a counsellor needs continuous self-improvement } \\
\text { and improvement. } \\
\text { 2. Counsellor work is more complicated. Therefore, } \\
\text { it is necessary to clarify the work ideas, optimize } \\
\text { the work mode, strengthen the exchange and } \\
\text { communication with students, and strengthen their } \\
\text { affinity. }\end{array}$ \\
\hline $\begin{array}{l}\text { Cadres and } \\
\text { troops of } \\
\text { students }\end{array}$ & $\begin{array}{l}\text { 1.give full play to the critical role of student cadres, } \\
\text { the formation of league branches and party branches. } \\
\text { 2. Improve the authority of student cadres, penetrate } \\
\text { the student groups, and enhance the common } \\
\text { language with students. }\end{array}$ \\
\hline $\begin{array}{l}\text { Class teacher } \\
\text { mentor team }\end{array}$ & $\begin{array}{l}\text { 1.stimulate the enthusiasm of classroom teachers for } \\
\text { educational management. } \\
\text { 2. To strengthen their sense of responsibility. } \\
\text { 3. Give full play to the important role of class } \\
\text { teacher mentors in teaching and educating students. }\end{array}$ \\
\hline
\end{tabular}

\subsection{Emphasis on strengthening the improvement of rules and regulations and implementing a humane student management}

As the saying goes, there are no rules and regulations, and art students are generally more disorganized ${ }^{[1]}$. At will, therefore, the school should improve all kinds of rules and regulations, and increase the implementation of efforts, to better implement the education and management of art students, student education work and student management work to integrate, to play the critical role of complementarity between the two ${ }^{[2]}$. In the ideological education of students, it is necessary to fully embody the concept of humane management, combining the moral and legal rule, see Table 3.

Table 3. Virtue and the rule of law

Concrete content

1.humane management and fully implement the concept of people-oriented education and

Rule by virtue management.

2.to educate and infect with their charisma and emotions. 1.he use of relevant rules and regulations to regulate and restrain the behaviour of students. 2.equal treatment of every student, every student needs to comply with the relevant rules and

The rule of law regulations, any student who violates the laws and regulations need to be punished accordingly. 3.Fair, just and open, so that every student can consciously abide by the relevant rules and regulations.

Virtue can well compensate for the deficiencies in the rule of law, the organic integration of morality and the rule of law while giving full play to the critical role of the two complements each other, the full implementation of the education management of art students ${ }^{[3]}$.

\subsection{Strengthening of campus culture}

In the process of implementing the education and management of art students, an energetic, artistic atmosphere of the school and management environment is essential, not only for the improvement of the effect of student education and management work, but also contribute to the formation of the artistic personality of students, both to teach the role of students, but also the part of infection ${ }^{[4]}$. Therefore, it is essential to strengthening the construction of campus culture, and the details are shown in Table IV.

Table 4. Measures and roles in building school culture

Campus culture-
building measures Important role

$\begin{aligned} & \text { 1.in the subtle inculcation and education } \\ & \text { of students, to create an excellent learning }\end{aligned}$
$\begin{aligned} & \text { Strengthening the } \\ & \text { culture of learning and environment for students. } \\ & \text { school culture }\end{aligned}$
$\begin{aligned} & \text { 2. Keep the students' good spirit and } \\ & \text { enterprising spirit. }\end{aligned}$

1.through the development of a variety of unique cultural and sports activities, active campus culture, to create a positive, healthy, upward learning atmosphere.

Enrichment of second- 2 . Through the arts, students will be class activities enlightened, encouraged to form a correct outlook on the three aspects of life, and cultivate the spirit of collectivism, patriotism and socialism.

\subsection{Strengthening psychological counselling for students majoring in the arts}

In today's environment of the rapid development of 
the market economy, the competition among talents is becoming more and more intense, increasing the psychological pressure on students. Especially art majors, because they need to pay expensive tuition fees every year, so in the fierce and cruel competitive environment, their reaction is usually more reliable than students of other majors, and it is easy to think of deviation. When these students are psychologically frustrated, or their wishes are unfulfilled, they often feel very depressed, anxious and other negative emotions, leading to some students' psychological imbalance, and finally to egoism, anger and different negative psychology ${ }^{[5]}$. Thus, it can be seen that art students are prone to mental problems and will harm their value orientation and personal behaviour. Some students choose to escape and indulge in virtual online games because they have nowhere to vent the pressure of student, life and employment. To solve this problem, it is necessary to strengthen the psychological counselling for students from the perspective of students' sound personality and correct three outlooks and build a perfect student counselling system, which mainly includes three aspects: study counselling, psychological counselling, and employment counselling. Besides, schools should also increase the investment in psychological counselling for art students and strengthen the propaganda of psychological counselling, to prompt more students to receive psychological advice on their own ${ }^{[6]}$. At the same time, the research on student psychological counselling work should be strengthened to promote the development of student counselling work towards the direction of scientific and standardization.

\subsection{Improving the cultural quality of art students}

A student with high ideological and moral quality and professional quality, it must have excellent cultural quality ${ }^{[7]}$. Therefore, in the implementation of art students' education management work process, should pay attention to strengthen the cultivation of students' artistic quality, to open up students' vision, activate students' thinking, cultivate students' sentiment, improve students' aesthetic quality at the same time, lay a good foundation for their future learning and development. For art students, the general focus on professional knowledge and skills, ignoring the teaching of basic cultural courses, resulting in the general aesthetic quality of art students is not very high. Usually, the moral condition is not very high. Thus, it is urgent to improve the overall quality of art students ${ }^{[8]}$. Therefore, the school should increase the establishment of regular courses, strengthen students' learning of the basic knowledge of culture, enrich students' knowledge structure, and expand students' knowledge system. Also, schools can add courses in the philosophy of art, sociology, aesthetics, literature, etc. according to their practical situations. And, purposefully and systematically infiltrate China's distinctive traditional culture into the teaching of educational courses and professional courses, to improve students' cultural and professional literacy while realizing the improvement of their humanistic scholarship, to export more quality artistic talents for society.

\subsection{Strengthening communication and interaction with students and respecting their individuality}

In the process of carrying out the management of art students' education and control, the teacher's role as a role model should be given full play to model for students. This requires that teachers, in general, must pay attention to maintain their right image, and continuously improve their overall quality, while asking students to do it themselves first, to take the lead ${ }^{[9]}$. Usually, teachers should strengthen the communication and communication between students, a comprehensive understanding of the dynamics of student thought, most of the art students are alone away from home to study here, some students will have a sense of helplessness and loneliness, then teachers must also give students enough care, and encourage students to help each other, in order to establish an excellent teacher-student relationship gradually and student-student relationship, while This will strengthen students' collective values and lay a good foundation for the smooth development of student education management. Also, art students in adolescence, still have a lack of understanding of things and do not have a wealth of experience in interpersonal relations, even ignorant of the world. In carrying out education management work, it is necessary to strengthen the analysis of students, to understand the actual situation of students, and according to the ideological characteristics of art, students to carry out education management work, respecting the personality of each student, not only to provide a flexible space for the personalized development of students but also thoughtful guidance and direction to students, to urge them to strive towards their ideals and goals ${ }^{[10]}$.

\section{Conclusion}

In summary, the art students' thoughts are unique, which also brings specific challenges to the management of student education. In the particular development 
of art students' education and management work, we should build "three teams", strengthen the improvement of rules and regulations, implement humane student management, and build a good campus culture, strengthen the psychological counselling for art students, communicate with students, respect students' personalities, and strengthen the management of art students. Students are trained in cultural literacy as a way to produce better quality arts professionals.

\section{References}

[1] Wang ZJ. Research on the ideological education and management model of art students in colleges and universities in the new period[J]. Think Tank Times, 2019, 186(18):200+205.

[2] Gu MM. The ideological and political education of high-ranking art majors picking up [J]. The Road to Success, 2019(24):23.

[3] Xu Q. Analysis of the effectiveness of ideological and political education of art students under the background of "Internet+" $+\mathrm{J}]$. Times Education, 2018(7): 121-121.

[4] Zhang H. How to effectively integrate the ideological and polit- ical education with the majors studied by art students[J]. Pop Color, 2019, 000(004):162-163.

[5] Cai NK. Analysis of the characteristics of senior art students and ideological and political education strategies [J]. Northern Literature, 2018, 000(011):209.

[6] Wang DD, Wang Yongliang. Problems and solution paths in the ideological and political education of art students in colleges and universities under the new situation [C] Jingchu Academic, October 2018 (General 24th Issue). 2019.

[7] Yao DQ. Analysis of the ideological and political education methods for art students in colleges and universities in the new media era[J]. Friends of Humanities, 2019, 000(010):99100.

[8] Jiang H. Exploration of new ideas on ideological and political education for students in art colleges and universities[J]. Friends of Humanities, 2018(12).

[9] Xue B. New characteristics of ideological dynamics and innovation of ideological and political education methods of college students under the perspective of psychological education[J]. Education Modernization, 2018, 5(46):177-179+224.

[10] Yi M. Exploration of ideological and political education methods of art college students under the new situation[J]. Leadership Science Forum, 2018. 